\title{
PENERAPAN PEMBELAJARAN MAKE A MATCH UNTUK MENINGKATKAN MINAT DAN HASIL BELAJAR MATEMATIKA KELAS I SEMESTER I DI SD NEGERI 4 PERTIMA TAHUN PEMBELAJARAN 2017/2018
}

\author{
Oleh \\ I Gusti Ayu Juniantari \\ SD Negeri 4 Pertima \\ igustiayu.juniantari@yahoo.co.id
}

diterima 7 Februari 2019, direvisi 15 Februari 2019, diterbitkan 29 April 2019

\begin{abstract}
ABSTRAK
Penelitian ini bertujuan untuk meningkatkan minat belajar dan hasil belajar matematika siswa kelas I Semester I SD Negeri 4 Pertima Tahun Pembelajaran 2017/2018 melalui implementasi model pembelajaran Make a Match. Untuk mencapai tujuan tersebut dilakukan penelitian tindakan pada siswa kelas I SD Negeri 4 Pertima Tahun Pelajaran 2017/2018 pada semester ganjil yang berjumlah 18 orang siswa. Penelitian ini dilakukan dalam dua siklus pembelajaran. Model pembelajaran yang digunakan dalam penelitian ini adalah model pembelajaran make a match. Obyek penelitian berupa minat dan hasil belajar siswa. Untuk mengukur minat belajar siswa digunakan pedoman obsevasi. Untuk mengukur hasil belajar siswa digunakan tes hasil belajar. Analisis data yang digunakan dalam penelitian ini adalah analisis deskriptif. Hasil analisis data diperoleh bahwa: 1) Penerapan model pembelajaran make a match sebagai alternatif menciptakan pembelajaran menyenangkan dapat meningkatkan minat belajar matematika siswa kelas I SD Negeri 4 Pertima Tahun Pembelajaran 2017/2018. Rata-rata minat belajar siswa siswa meningkat dari 68,49 pada siklus I dengan kategori sedang menjadi 79,13 pada siklus II dengan kategori tinggi. Hal ini mengindikasikan terjadi peningkatan minat belajar siswa sebesar 15,5\%. 2) Penerapan model pembelajaran make a match sebagai alternatif menciptakan pembelajaran menyenangkan dapat meningkatkan hasil belajar matematika siswa kelas I SD Negeri 4 Pertima Tahun Pemblajaran 2017/2018. Rata-rata hasil belajar Matematika siswa 69,4 dengan ketuntaan klasikal 78\%, pada siklus II diperoleh rata-rata hasil belajar siswa 88,9 dengan ketuntasan klasikal $100 \%$, hal ini mengindikasikan terjadi peningkatan hasil belajar Matematika sebesar $28 \%$.

Hasil belajar dalam pembelajaran akan lebih baik apabila sebelum melakukan proses belajar mempersiapkan perangkat pembelajaran yang dibutuhkan dengan matang dan terencana terlebih dahulu agar mencapai tujuan pembelajaran yang diinginkan. Dalam melakukan proses pembelajaran yang dilakukan, sesederhana apapun hendaknya guru dalam mengajar mengupayakan menggunakan media pembelajaran, guna menarik perhatian siswa dalam belajar. Gunakan media pembelajaran melalui model pembelajaran yang melibatkan keaktifan siswa dalam belajar matematika seperti di SD negeri 4 Pertima yang ada di Kecamatan Karangasem, Kabupaten Karangasem Bali.
\end{abstract}

Kata-kata kunci:Model Pembelajaran Make a Match, Minat Belajar, Hasil Prestasi Matematika 


\section{PENDAHULUAN}

Mata pelajaran matematika, merupakan mata pelajaran yang membahas masalah tentang kemampuan menambah, mengurangi, mengalikan, membagi, mengukur dan memahami bentuk geometri, perlu diberikan kepada semua siswa mulai dari jenjang sekolah dasar guna membekali siswa agar mampu berpikir logis, analitis, sistematis, kritis dan kreatif serta mampu bekerja sama. Kompetensi tersebut diperlukan agar peserta didik memiliki kemampuan memperoleh, mengelola dan memanfaatkan informasi di era globalisasi ini.

Dalam pembelajaran Matematika di sekolah dasar, agar bahan pengajaran yang disampaikan menjadi lebih mudah dipahami oleh siswa, diperlukan alat bantu pembelajaran, juga pemilihan strategi, pendekatan, metode dan teknik pembelajaran yang menarik dan tepat dapat membantu peneliti dan siswa dalam mencapai tujuan pembelajaran.

Agar siswa dapat mencapai kompetensi yang diharapkan dalam pelajaran matematika, peneliti dituntut mempunyai kompetensi terhadap tugasnya.Salah satunya adalah peneliti harus mampu menggunakan berbagai pendekatan pembelajaran agar siswa tidak menjadi bosan. Mengajak dan menjaga agar siswa tetap belajar adalah tugas peneliti dalam rangka menjaga semangat belajar siswa. Tidak hanya terbatas pada seberapa materi yang dikuasainya, hal yang tidak kalah penting untuk dikuasainya yaitu bagimana menggunakan suatu pendekatan tertentu dalam proses pembelajaran. Memilih pendekatan pembelajaran yang tepat dalam suatu proses belajar berarti peneliti sedang mengatur strategi pembelajaran.
Adapaun yang dimaksud dengan strategi dalam Kamus Besar Bahasa Indonesia strategi adalah rencana yang cermat mengenai kegiatan untuk mencapai sasaran khusus.

Namun kenyataannya, hasil belajar siswa masih di bawah KKM yang ditetaapkan di sekolah. Mengenai rendahnya hasil pembelajaran Matematika tentang pengukuran satuan waktuyang kami lakukan, setelah dikoreksi hasil tes tertulis dari18 siswa kelas I yang mengikuti tes, 12 siswa (60\%) belum memperoleh hasil yang diharapkan (tidak tuntas). Kriterira Ketuntasan Minimal (KKM) yang ditetapkan untuk mata pelajaran Matematika adalah 70. Sehingga kalau nilai anak kuranng dari 70 dinyatakan belum tuntas. Daya seraap siswa kelas 1 di SD Negeri 4 Pertima baru mencapai $55 \%$. Hal ini perlu mendapat perhatian serius dari peneliti. Peneliti sebagai pelaku pendidikan harus bertanggung jawab untuk memperbaikiagar pembelajarandapat mencapai tujuan dengan baik.

Oleh sebab itu peneliti melakukan refleksi, apa yang telah terjadi selama pembelajaran. Sebab materi ini sebagai dasar untuk materi selanjutnya, sehingga bila tidak segera dipecahkan akan semakin tidak baik hasil pembelajaran selanjutnya. Berdasarkan masalah tersebut di atas, penulis melakukan refleksi dan kolaborasi dengan teman sejawat, untuk mencari akar permasalahan. Dari kegiatan tersebut. Salah satu model pembelajaran yang pas buat siswa adalah model pembelajaran $A$ Match. Model pembelajaran make a match adalah sistem pembelajaran yang mengutamakan penanaman kemampuan sosial terutama kemampuan bekerja sama, 
kemampuan berinteraksi disamping kemampuan berpikir cepat melalui permainan mencari pasangan dengan dibantu kartu (Winataputra, 2004).

Berdasarkan paparan tersebut, peneliti selaku guru kelas di SD Negeri 4 Pertima mengupayakan suatu perbaikan dalam proses pembelajaran melalui penelitian tindakan kelas yang berjudul Penerapan Model Pembelajaran make a match Sebagai Alternatif Menciptakan Pembelajaran Menyenangkan Untuk Meningkatkan Minat Belajar dan Hasil Belajar Matematika Siswa Kelas I SD Negeri 4 Pertima Tahun Pelajaran 2017/2018. Penelitian ini merupakan penelitian tindakn yang peneliti lakukan untuk mengadakan perbaikan proses pembelajaran untuk mencapai hasil yang diharapkan.

\section{METODE}

Tempat pelaksanaan tindakan adalah di SD Negeri 4 Pertima dengan mengambil subjek penelitian siswa kelas I semester I yang berjumlah 18 orang siswa. Alasan peneliti mengambil tempat penelitian di SD Negeri 4 Pertima adalah: a)Peneliti bertugas sebagai guru kelas I di SD Negeri 4 Pertima, sehingga peneliti menemukan permasalahan masih kurangnya hasil belajar siswa pada mata pelajaran Matematika yang disebabkan oleh rendahnya minat siswa belajar matematika.

Objek penelitian terdiri dari dua yaitu objek tindakan dan objek pengamatan. Objek tindakan yang digunakan dalam penelitian ini adalah penerapan model pembelajaran make a match untuk menciptakan pembejaran yang menyenangkan. Objek pengamatan dalam penelitian ini adalah minat belajar siswa terhadap pembelajaran Matematika dan hasil belajar Matematika siswa.
Penelitian ini dilakukan sesuai dengan jadwal pelajaran yang ada di sekolah yaitu pada hari Rabu dan Jumat. Proses pembelajaran Matematika dilaksanakan dalam empat jam pelajaran, dimana 1 jam pelajaran adalah 35 menit. Dalam seminggu pertemuan pembelajaran sebanyak 2 kali pertemuan ( $4 \times 35$ menit).

Pelaksanaan Pembelajaran dan Perbaikan Pembelajaran terdiri dari 2 siklus. Masing-masing siklus meliputi perencanaan, pelaksanaan, observasi dan refleksi. Data yang dikumpulkan dalam penelitian ini adalah 1) minat belajar Matematika, dan 2) prestasi belajar Matematika siswa melalui implementasi model pembelajaran Make A Match. Metode yang digunakan untuk menganalisis data hasil penelitian ini adalah metode deskriptif kuantitatif. Untuk data kuantitatif dianalisis dengan mencari mean, standar deviasi, membuat interval kelas dan melakukan penyajian dalam bentuk tabel dan grafik. Skor rata-rata minat belajar matematika siswa yang diperoleh dari perhitungan dibandingkan dengan skor penggolongan yang telah ditetapkan. Skor rata-rata minat belajar siswa dianalisis dengan rumus:

$=\frac{\sum \mathrm{X}}{\mathrm{N}}$ dimana :

$\overline{\mathrm{X}} \quad=$ skor rata-rata minat belajar Matematika

$\sum \mathrm{X}=$ jumlah seluruh skor

$\mathrm{N}=$ jumlah siswa (Arikunto,

2002)

Skor rata-rata minat belajar Matematika siswa yang diperoleh dari perhitungan dibandingkan dengan skor penggolongan minat belajar Matematika seperti pada Tabel 3.5. Kriteria keberhasilan penelitian ini 
adalah jika sikap siswa minimal berada pada kategori tinggi.

Data hasil belajar siswa dianalisis secara deskriptif, yaitu dengan menentukan nilai hasil belajar siswa yang diperoleh melalui tes. Setelah diperoleh skor siswa, selanjutnya dicari skor rata-rata prestasi belajar siswa $(\bar{X})$ dengan rumus:

$$
\bar{X}=\frac{\Sigma X}{N}
$$

Keterangan:

$\sum \bar{X} \quad=$ jumlah skor hasil belajar siswa

$$
\mathrm{N} \quad \text { = banyak siswa }
$$

Ketuntasan klasikal dihitung dengan rumus sebagai berikut.

$\mathrm{KK}=$

Banyaknya Siswa yang memperoleh nilai $\geq 70$ banyak siswa yang ikut tes

\section{PEMBAHASAN}

Siklus I dilaksanakan pada
bulan Agustus sampai dengan September 2017. Tahapan penelitian di siklus I dimaluai dari tahap perencanaan penelitian (menyusun proposal dan perencanaan tindakan siklus I), tahap pelaksanaan penelitian (implementasi model pembelajaran make a match), tahap pengumpulan data/observasi (mengambil data minat belajar, tes hasil belajar), dan tahap evaluasi refleksi (menganalisis data hasil penelitian untuk menyimpulkan hasil pembelajaran di siklus I. Meminta teman guru bidang studi sejenis/rekan sejawat sebagai mitra kesejawatan dalam pelaksanaan pembelajaran yang sudah direncanakan. Hasilnya adalah kesiapan teman-teman guru untuk ikut melaksanakan supervisi kunjungan kelas dalam mengamati kekurangan yang ada. Rekan sejawat juga berguna membantu dalam mengobservasi minat belajar siswa.
Siswa dikatakan tuntas jika $\bar{X} \geq 70$ dan satu kelas dikatakan tuntas jika $\mathrm{KK} \geq 85 \%$. Hal ini sesuai dengan kreteria yang ditetapkan oleh SD Negeri 4 Pertima pada semester ini. Penelitian ini dikatakan berhasil jika rata-rata $(\bar{X})$ pencapaian minimal 70 dan ketuntasan klasikalnya (KK) minimal $85 \%$.

Peningkatan untuk aspek hasil belajar ini dianalisis dari rata-rata skor yang diperoleh oleh siswa dalam satu kelas $(\bar{X})$ pada siklus I dibandingkan dengan rata-rata yang diperoleh siswa pada siklus II. Aspek hasil belajar siswa dikatakan meningkat jika ratarata nilai prestasi belajar siklus II lebih besar dari rata-rata siklus I ( $\bar{X}$ siklus II $>\bar{X}$ Siklus I $>\bar{X}$ sebelum penelitian).

a) Menyusun format pengecekan yang berhubungan minat belajar siswa untuk masing-masing pertemuan.

b) Teman guru yang diminta mengamati pembelajaran diupayakan pembekalan tentang model pembelajaran ini dengan:

1) Rekan sejawat harus sudah mantap dan mengetahui metode pembelajaran yang menggunakan make a match dan kehadirannya di kelas bukan mencari kesalahan, tetapi untuk kepentingan bersama yaitu memperbaiki pembelajaran.

2) Rekan sejawat telah diberitahu untuk lebih memahami tentang prinsip-prinsip supervisi sehingga tidak lagi cenderung instruktif dan lebih bersahabat dengan prinsip kesejawatan.

3) Dalam pelaksanaan pembelajaran, rekan sejawat diharapkan menunjukkan rasa kesejawatan yang akrab dan mau menilai kebenaran yang ada. 
http://ejournal.ihdn.ac.id/index.php/AW

c) Peneliti memberikan penjelasan pada siswa bahwa kehadiran rekan sejawat ke kelas bukan untuk mencari kesalahan atau kelemahan guru dalam pembelajaran, tapi untuk meningkatkan kemampuan siswa menguasai ilmu.

d) Merencanakan pembagian materi pembelajaran yang disesuaikan dengan Standar Kompetensi, Kompetensi Dasar, dan Indikator untuk masing-masing siklus dan setiap pertemuan.

e) Memilih dan mengorganisaasikan materi, media, dan sumber belajar.

Pada siklus pertama ini, peneliti mengorganisasikan materi pembelajaran dengan baik. Urutan penyampaiannya dari yang mudah ke yang sulit, cakupan materi cukup bermakna bagi siswa, menentukan alat bantu mengajar. Sedangkan dalam penentuan sumber belajar sudah disesuaikan dengan tujuan, materi pembelajaran dan tingkat perkembangan peserta didik.

f) Merancang skenario pembelajaran.

Skenario pembelajaran disesuikan dengan tujuan, materi dan tingkat perkembangan siswa, diupayakan variasi dalam penyampaian. Susunan dan langkah-langkah pembelajaran sudah disesuaikan dengan tujuan, materi, tingkat perkembangan siswa, waktu yang tersedia, sistematiknya adalah menaruh siswa dalam posisi sentral menyesuaikan dengan model pembelajaran make a match .

Setelah semua komponen baik fisik maupun mental sudah siap maka barulah peneliti melaksanakan proses pembelajaran sesuai dengan waktu yang ditetapkan.

\section{Evaluasi Data Siklus I}

Data yang dikumpulkan kemudian dianalisis secara deskriptif. Hasil penelitian yang dilaporkan pada siklus I memuat data minat belajar Matematika dan hasil belajar Matematika siswa.

\section{a) Minat Belajar}

Data minat belajar siswa dikumpulkan dengan menggunakan pedoman observasi di masing-masing proses pembelajaran siklus I. Hasil rekapitulasi minat belajar siswa siklus I disajikan pada Tabel 1.

Tabel 1

Data Minat Belajar Siklus 1

\begin{tabular}{|c|c|c|c|c|}
\hline No & Kriteria & $\begin{array}{c}\text { Rentang } \\
\text { Skor }\end{array}$ & Frekuensi & Persentase \\
\hline 1 & Sangat Tinggi & $86-100$ & 0 & $0 \%$ \\
\hline 2 & Tinggi & $70-85$ & 8 & $44 \%$ \\
\hline 3 & Sedang & $55-69$ & 10 & $56 \%$ \\
\hline 4 & Rendah & $40-54$ & 0 & $0 \%$ \\
\hline 5 & $\begin{array}{l}\text { Sangat } \\
\text { Rendah }\end{array}$ & $<40$ & 0 & $0 \%$ \\
\hline \multicolumn{3}{|c|}{ Rata-rata } & 68,5 & Sedang \\
\hline
\end{tabular}

Berdasarkan Tabel 1 diketahui bahwa rata-rata minat belajar siswa pada siklus I memiliki adalah 68,5. tampak bahwa minat belajar siklus I berada 
pada sebaran kualifikasi sedang sampai dengan tinggi dengan masingmasing persentase yaitu: sedang $56 \%$, dan tinggi $44 \%$. Secara umum minat belajar Matematika siswa kelas I SD Negeri 4 Pertima tahun pelajaran 2017/2018 adalah berkategori sedang.

\section{b) Hasil Belajar Matematika}

Hasil belajar dikontribusikan tes formatif di akhir siklus I sehingga pada akhir siklus diperoleh nilai rata- rata hasil belajar siswa. Tes hasil belajar yang digunakan pada siklus I adalah tes pilihan ganda dengan 10 butir pertanyaan. Cakupan materi yang digunakan adalah menyangkut namanama hari selama sepekan. Rekapitulasi hasil belajar siklus I disajikan pada Tabel 4.3.

Rekapitulasi hasil belajar Matematika siklus I dapat dilihat pada table 2 .

Table 2

Data Hasil Belajar Matematika Siklus 1

\begin{tabular}{||c|l|c|}
\hline No & \multicolumn{1}{|c|}{ Indikator } & Hasil Analisis \\
\hline 1 & Nilai Terendah & 50 \\
\hline 2 & Nilai Tertinggi & 80 \\
\hline 3 & Jumlah Nilai & 1250 \\
\hline 4 & Rata-rata hasil belajar & 69,44 \\
\hline 5 & Banyak siswa yang memperoleh nilai $\geq 70$ & 14 \\
\hline 6 & Prosesntase siswa yang memperoleh nilai $\geq 70$ & $78 \%$ \\
\hline 7 & Banyak siswa yang memperoleh nilai < 70 & 4 \\
\hline 8 & Prosesntase siswa yang memperoleh nilai $<70$ & $22 \%$ \\
\hline
\end{tabular}

Berdasarkan Tabel 2 diperoleh bahwa nilai rata-rata hasil belajar siswa adalah 69,4; skor minum adalah 50 dan skor maksimumnya 80 . Ketuntasan belajar siswa kelas I SD Negeri 4 Pertima pada siklus I adalah $78 \%$. Hasil ini masih dibawah standar yang ditetapkan di SD Negeri 4 Pertima dengan rata-rata ketuntasan belajar 70 dan ketuntasan klasikal sebesar $85 \%$.

\section{Pembelajaran Siklus II}

Siklus II dilaksanakan pada bulan Oktober 2017. Pelaksanaan tindakan siklus II disesuaikan dengan hasil refleksi pada siklus I, dengan melakukan beberapa tindakan perbaikan seperti yang telah diuraikan pada pembahasan hasil refleksi pada siklus I. Proses pembelajaran pada siklus II dikemas menjadi 3 kali pertemuan. Pertemuan pertama siswa belajar tentang mengurutkan namanama hari. Guru membuka pelajaran dengan menyampaikan salam pembuka, mengabsensi siswa secara umum, menyampaikan kompetensi dasar, dan indikator hasil belajar siswa. Guru selanjutnya memfokuskan siswa untuk belajar dengan memberikan apersepsi dan motivasi untuk mengarahkan siswa kepada materi tentang urutan nama-nama hari.

Kegiatan inti pembelajaran dimulai dengan fase pemusatan. Guru menyiapkan beberapa lembar gambar yang diacak dalam sebuah kardus. Selain gambar guru menyiapkan lembar kerja siswa yang merupakan bagian dari urutan nama hari yang 
tidak lengkap. Siswa nanti akan melengkapi tabel tersebut dengan cara menempelkan gambar-gambar yang bersesuaian di depan kelas. Guru menekankan aturan belajar dan juga menyampaikan hadiah motivasi bagi siswa yang endapatkan hasil tebaik dalam belajar di siklus II. Setelah siswa paham dengan aturan permainan dalam pembelajaran, pembelajaran dilanjutkan ke fase pengorganisasian. Siswa diminta duduk ke dalam kelompoknya masing-masing dan membagi diri ke dalam tugas-tugas yang akan dilakukan. Setelah semua siswa duduk dalam kelompoknya dan memiliki tugas masing-masing, siswa mengambil LKS ke depan kelas dan mencermati lembar kerja tersebut dengan baik. Jika ada hal yang belum jelas siswa diminta bertanya kepada guru. Tahap selanjutnya adalah fase elaborasi. Tahap elaborasi ini merupakan tahap utama dari model pembelajaran make a match. Perwakilan siswa diminta untuk mengambil satu gambar ke depan. Setelah mendapatkan gambar siswa kembali ke kelompoknya masingmasing. Guru menyediakan waktu 5 menit kepada masing-masing kelompok untuk menempelkan gambar tersebut ke depan. Siswa kedua selanjutnya mengambil gambar, jika terjadi kesamaan pengambilan gambar pertama dengan gambar kedua maka gambar dikembalikan lagi dan siswa mendapatkan kesematan mengambil gambar kembali. Setelah semua kelompok mendapatkan gambar, kembali ke kelompoknya masingmasing dan menempelkanya seperti gambar pertama. Kegiatan pembelajaran terus dilakukan sehingga setiap kelompok menempelkan lima gambar berbeda di LKS. Tahap selanjutnya adalah fase konfrimasi dan refleksi. Siswa diminta menyampaikan hasil elaborasi kelompoknya di depan kelas, siswa yang lain diminta menanggapi hasil diskusi tersebut. Sebelum pembelajaran berakhir, guru meminta siswa untuk menyampaikan pesan dan kesan pembelajaran yang telah berlangsung. Pembelajaran ditutup oleh guru dengan mengucapkan salam penutup, dan meminta siswa untuk mempersiapkan diri lebih baik di rumah sebelum pembelajaran berlangsung.

Pertemuan kedua siswa belajar menyebutkan hari besok, lusa, kemarin dan seterusnya. Secara umum proses pembelajaran yang berlangsung sama persis. Semua siswa hadir dalam proses pembelajaran. Diakhir permbelajaran guru menyampaikan kepada siswa bahwa pada pertemuan selanjutnya akan diadakan tes akhir siklus II. Tes yang diberikan adalah 6 butir tes isian. Pelaksanaan diskusi siklus kedua ini mengalami peningkatan dari pada siklus I, di mana hal ini merupakan hasil positif dari refleksi dan perbaikan-perbaikan yang telah dilakukan terhadap kekurangan pembelajaran pada siklus I. Siswa sudah mulai terbiasa dalam mengikuti langkah pembelajaran yang dibelajarkan sehingga siswa dapat lebih mandiri dalam memecahkan persoalan yang ada pada LKS. Siswa sudah mampu menemukan konsepkonsep yang digunakan untuk menjawab pertanyaan yang ada pada LKS, baik dengan jalan memperoleh jawaban informasi melalui buku atau melalui sharing pendapat bersama teman dalam satu kelompoknya. Guru melakukan bimbingan dan memfasilitasi siswa untuk mengatasi masalah yang dihadapi siswa. Hal ini dapat memotivasi siswa untuk menemukan konsep-konsep yang penting terkait dengan permasalahan dan pokok bahasan yang dikaji 
sehingga memperoleh penjelasan berupa pemecahan masalah yang terdapat pada LKS. Guru masih tetap memeriksa bahwa setiap anggota kelompok dapat menyelesaikan permasalahan yang terdapat pada lembar kerja untuk mengetahui tingkat pemahaman siswa. Guru mengintensifkan bimbingan kepada kelompok yang masih belum tuntas dalam menyelesaikan tugasnya sehingga setiap anggota kelompok dapat memahami materi yang dipelajari.

Berdasarkan presentasi yang dilakukan oleh kelompok, minat siswa sudah terjadi peningkatan. Guru selanjutnya menanggapi hasil pekerjaan kelompok dan diskusi secara umum serta menaggapi konsep-konsep yang dikemukakan siswa agar siswa dapat mengevaluasi sendiri pengetahuan yang telah dibentuk sebelum atau selama proses pembelajaran. Observasi minat siswa dilakukan mulai dari awal kegiatan pembelajaran. Pembelajaran yang dilakukan siswa sudah bergairah, pembelajaran mengarah pada pembelajaran menyenangkan. Hal ini tampak tari antusiasme siswa bermain sambil belajar.

a) Minat Belajar Matematika

Data minat belajar siswa dikumpulkan dengan menggunakan pedoman observasi di masing-masing pertemuan. Hasil rekapitulasi minat belajar siswa siklus II disajikan pada Tabel 3.

Tabel 3

Rekapitulasi Minat Belajar Siswa Siklus II

\begin{tabular}{|c|c|c|c|c|}
\hline No & Kriteria & Rentang Skor & Frekuensi & Persentase \\
\hline 1 & Sangat Tinggi & $86-100$ & 2 & $11 \%$ \\
\hline 2 & Tinggi & $70-85$ & 16 & $89 \%$ \\
\hline 3 & Sedang & $55-69$ & 0 & $0 \%$ \\
\hline 4 & Rendah & $40-54$ & 0 & $0 \%$ \\
\hline 5 & Sangat Rendah & $<40$ & 0 & $0 \%$ \\
\hline \multicolumn{3}{|c|}{ Rata-rata } & 79,13 & Tinggi \\
\hline
\end{tabular}

Berdasarkan Tabel 3 diketahui bahwa rata-rata minat belajar siswa pada siklus II memiliki adalah 79,13. Kualifikasi minat belajar siswa pada siklus II adalah berada pada kategori tinggi. Kualifikasi tinggi 89\%, dan sangat tinggi $11 \%$. Secara keseluruhan rata-rata minat belajar Matematika siswa kelas I SD Negeri 4 Pertima sebesar 79,13 dengan kualifikasi tinggi.

\section{b) Hasil Belajar Matematika}

Hasil belajar dikontribusikan tes formatif di akhir siklus II sehingga pada akhir siklus diperoleh nilai ratarata hasil belajar siswa. 
Tabel 4

Rekapitulasi Hasil Belajar Siklus II

\begin{tabular}{|c|l|c|}
\hline No & \multicolumn{1}{|c|}{ Indikator } & Hasil Analisis \\
\hline 1 & Nilai Terendah & 83,33 \\
\hline 2 & Nilai Tertinggi & 100 \\
\hline 3 & Jumlah Nilai & 1600 \\
\hline 4 & Rata-rata hasil belajar & 88,89 \\
\hline 5 & Banyak siswa yang memperoleh nilai $\geq 70$ & 18 \\
\hline 6 & Prosesntase siswa yang memperoleh nilai $\geq 70$ & $100 \%$ \\
\hline 7 & Banyak siswa yang memperoleh nilai < 70 & 0 \\
\hline 8 & Prosesntase siswa yang memperoleh nilai $<70$ & $0 \%$ \\
\hline
\end{tabular}

Berdasarkan Tabel 4 diperoleh bahwa nilai rata-rata hasil belajar siswa adalah 88,89 dengan rentang skor dari 83 sampai dengan 100 . Ketuntasan belajar Matematika yang dicapai siswa pada akhir siklus II adalah $100 \%$, diperoleh nilai rata-rata hasil belajar Matematika siswa kelas I SD Negeri 4 Pertima pada siklus II adalah 88,89 dengan ketuntasan klasikal $100 \%$. Penelitian dikatakan berhasil jika nilai rata-rata siswa lebih besar atau sama dengan 70 dan ketuntasan klasikal siswa lebih besar atau sama dengan $85 \%$. Nilai rata-rata minat belajar siswa siswa meningkat dari 68,49 pada siklus I dengan kategori sedang menjadi 79,13 pada siklus II dengan kategori tinggi. Hal ini mengindikasikan terjadi peningkatan minat belajar siswa sebesar $15,5 \%$. Hasil pada siklus II sudah sesuai dengan kriteria keberhasilan tindakan yaitu minat belajar siswa berada pada kategori tinggi. Berdasarkan hasil tersebut, dapat disimpulkan bahwa penerapan model pembelajaran make a match dapat meningkatkan minat belajar siswa.

Tabel 5

Perbandingan Nilai Hasil Belajar Siswa

\begin{tabular}{|c|l|c|c|}
\hline No & \multicolumn{1}{|c|}{ Indikator } & Siklus I & Siklus II \\
\hline 1 & Nilai Terendah & 50 & 83 \\
\hline 2 & Nilai Tertinggi & 80 & 100 \\
\hline 3 & Jumlah Nilai & 1250 & 1600 \\
\hline 4 & Rata-rata hasil belajar & 69,4 & 88,9 \\
\hline 5 & Banyak siswa yang memperoleh nilai $\geq 70$ & 14 & 18 \\
\hline 6 & Prosesntase siswa yang memperoleh nilai $\geq 70$ & $78 \%$ & $100 \%$ \\
\hline 7 & Banyak siswa yang memperoleh nilai $<70$ & 4 & 0 \\
\hline 8 & Prosesntase siswa yang memperoleh nilai $<70$ & $22 \%$ & $0 \%$ \\
\hline
\end{tabular}


Berdasarkan Tabel 5, tampak bahwa pada siklus I rata-rata hasil belajar Matematika siswa 69,4 dengan ketuntaan klasikal $78 \%$. Hasil ini belum sesuai dengan kriteria keberhasilan tindakan. Siswa dikatakan berhasil adalam blajar jika memiliki hasil belajar Matematika minimal 70 dan ketuntasasan klasikal minimal $85 \%$. Setelah diadakan perbaikan pembelajaran di siklus II diperoleh rata-rata hasil belajar siswa 88,9 dengan ketuntasan klasikal $100 \%$. Berdasarkan Gambar 4.6 dan Tabel 4.8, tampak terjadi peningkatan hasil belajar Matematika siswa dari siklus I sebesar 69,4 ke siklus II sebesar 88,9, hal ini mengindikasikan terjadi peningkatan hasil belajar Matematika sebesar $28 \%$. Berdasarkan hasil tersebut dapat disimpulkan bahwa penerapan model pembelajaran make a match dapat meningkatkan hasil belajar siswa.Pendapat orang lain dalam memecahkan masalah.

\section{SIMPULAN}

$$
\text { Penerapan model }
$$

pembelajaran make a match sebagai alternatif menciptakan pembelajaran menyenangkan dapat meningkatkan minat belajar matematika siswa kelas I SD Negeri 4 Pertima Tahun pembelajaran 2017/2018. Rata-rata minat belajar siswa siswa meningkat dari 68,49 pada siklus I dengan kategori sedang menjadi 79,13 pada siklus II dengan kategori tinggi. Hal ini mengindikasikan terjadi peningkatan minat belajar siswa sebesar 15,5\%. Penerapan model pembelajaran make a match sebagai alternatif menciptakan pembelajaran menyenangkan dapat meningkatkan hasil belajar matematika siswa kelas I SD Negeri 4 Pertima Tahun Pembelajaran 2017/2018. Rata-rata
http://ejournal.ihdn.ac.id/index.php/AW

hasil belajar Matematika siswa 69,4 dengan ketuntaan klasikal 78\%, pada siklus II diperoleh rata-rata hasil belajar siswa 88,9 dengan ketuntasan klasikal 100\%, hal ini mengindikasikan terjadi peningkatan hasil belajar Matematika sebesar $28 \%$.

\section{DAFTAR PUSTAKA}

Arikunto, Suharsimi, 2002. Penelitian Tindakan Kelas. Jakarta: PT Bumi Aksara.

Arikunto, Suharsimi. 2006. DasarDasar Evaluasi Pendidikan. Jakarta: Bumi Aksara.

Arikunto, Suharsimi; Suhardjono; Supardi. 2006. Penelitian Tindakan Kelas. Jakarta: PT Bumi Aksara.

Arnyana, I.B.P.2004. Pengembangan Perangkat Model Belajar Berdasarkan Masalah Dipandu Strategi Kooperatif serta Pengaruh Implementasinya terhadap Kemampuan Berpikir Kritis dan Hasil Belajar Siswa Sekolah Menengah Atas pada Pelajaran Ekosistem. Disertasi (tidak diterbitkan). Universitas Negeri Malang.

Crow, L.D \& Alice Crow. 1989, Psycology Pendidikan.

Terjemahan Abd. Rachman Abror. Educational Psycology. Hyogyakarta: Nur Cahaya.

Dimyati. 1999. Belajar dan

Pembelajaran. Jakarta: Depdikbud.

Dimyati dan Mudjiono. 2006. Belajar dan Pembelajaran. Jakarta: Rineka Cipta.

Djamarah, Syaiful Bahri. 2002. Psikologi Belajar. Jakarta: PT. Rineka Cipta. 
ADI WIDYA: Jurnal Pendidikan Dasar Volume. 4, Nomor 1 April 2019

ISSN: 2527-5445

http://ejournal.ihdn.ac.id/index.php/AW

Ernis, Agustina. 2011. Penerapan Model Kooperatif Make a Match untuk Meningkatkan Pembelajaran IPA Siswa Kelas III di SDN Tanjungrejo 5 Kecamatan Sukun Kota Malang. Skripsi. Salatiga: FKIP Universitas Kristen Satya Wacana.

Hurlock, Elizabeth B. 1994. Psikologi Perkembangan : Suatu Pendekatan Sepanjang rentang Kehidupan, Jakarta : Erlangga.

Istoqomah, Sya 2011. Penerapan Model Pembelajaran Kooperatif Tipe Make A Match Untuk Meningkatkan
Motivasi dan Hasil Belajar Siswa Mata Pelajaran IPS Siswa Kelas V Semester II SD Negeri 16 Surakarta Tahun Ajaran 2009/2010. Skripsi. Salatiga: FKIP Universitas Kristen Satya Wacana.

Lasmawan, I W. 2003. Penelitian Tindakan Kelas. (PTK). Singaraja: IKIP Singaraja.

Lorna Curran. 1994. Metode Pembelajaran Make a Match. Jakarta: Pustaka Belajar.

Mulyasa, E. 2009. Menjadi Guru Profesional Menciptakan Pembelajaran Kreatif dan Menyenangkan. Bandung: Remaja Rosdakarya. 